\title{
Les concepcions de l’alumnat sobre la nutrició humana i com han evolucionat al llarg d’una Unitat Didàctica
}

\author{
David Ferrer Sánchez (david.ferrer.sanchez@uab.cat) Estudiant de Doctorat al Centre de Recerca per a \\ l'Educació Científica i Matemàtica (CRECIM). \\ Roser Pintó Casulleras (roser.pinto@uab.cat) Professora emèrita de la Universitat Autònoma de Barcelona \\ (UAB). Centre de Recerca per a l'Educació Científica i Matemàtica (CRECIM).
}

La nutrició humana és un dels temes més essencials en l'Educació Secundària degut a la seva relació amb la salut humana. Des d'un punt de vista socioconstructivista, les concepcions alternatives de l'alumnat relacionades amb els fenòmens de la nutrició humana són molt importants perquè el procés d'ensenyament $i$ aprenentatge s'ha de basar en la reconstrucció del coneixement a partir d'aquestes concepcions. Per aquest propòsit, s'ha dissenyat i implementat una Unitat Didàctica sobre la nutrició humana. En aquest treball, s'han analitzat i discutit en profunditat els resultats obtinguts abans, durant i després de la implementació al voltant de tres objectius principals: analitzar les connexions entre els processos involucrat en la nutrició humana, identificar les concepcions alternatives associades a aquestes connexions i estudiar la evolució de les concepcions alternatives després de la implementació.

Paraules clau: Nutrició humana, educació secundària, concepcions alternatives, model integrat, evolució.

Human nutrition is one of the most essential issues in high school education due to its relationship with human health. From a socioconstructivistic point of view, the students' misconceptions related to the phenomena of human nutrition are very important because the teaching and learning process should be based on the knowledge reconstruction from these misconceptions. For that propose, a Didactic Unit about human nutrition has been designed and implemented. In this work, the results before, during and after the implementation have been analyzed and discussed in depth around three main objectives: to analyze the connection between processes involved in human nutrition, to identify the misconceptions associated with these connections and to study the evolution of the misconceptions after the implementation.

Keywords: Human nutrition, high school education, misconceptions, integrated model, evolution

\section{INTRODUCCIÓ}

La nutrició humana és un tema molt important a treballar en l'Educació Secundària degut a la seva implicació en qüestions de salut que qualsevol ciutadà competent hauria de conèixer i que són properes a la realitat de l'alumnat, tals com l'obesitat o l'anorèxia. Per exemple, parlar d'anorèxia implica parlar de com el fet de no ingerir els nutrients necessaris per a l'obtenció de l'energia que necessiten les nostres cèl-lules per viure, fa que el nostre organisme a la llarga acabi obtenint energia de la degradació de proteïnes pròpies que estan destinades a altres funcions, el que pot causar el desenvolupament d'altres malalties i, en casos extrems, fins i tot la mort. Per aquest motiu, la comprensió i la integració dels diversos processos que engloben la nutrició humana, des de la ingesta d'aliments fins a la producció de residus, passant per les cèl-lules i la obtenció de matèria i energia; resulten essencials per tal d'entendre els efectes de l'alimentació en la salut. 
Un dels problemes més habituals que s'identifica en l'ensenyament de les ciències i, per tant, també en l'ensenyament de la nutrició humana, és que les idees que expressa l'alumnat en relació a diversos fenòmens no sempre es corresponen a les idees àmpliament acceptades per la ciència. Aquestes idees que apareixen abans de l'ensenyament formal i que estan molt arrelades en el propi alumnat han rebut diverses terminologies al llarg de la història, però per facilitar la lectura i referir-nos a un únic terme al llarg de l'article nosaltres anomenarem concepcions alternatives.

Des d'una perspectiva socioconstructivista, descobrir i fer explícites quines són aquestes concepcions alternatives és imprescindible per tal de conèixer els principals problemes que presentarà l'alumnat i poder dissenyar activitats específiques que els generin conflictes cognitius, els quals els obliguin a replantejar les seves concepcions i a canviar-les per noves que estiguin més d'acord amb el model científic.

Les recerques en didàctica de les ciències que s'han desenvolupat entorn els processos que formen part de la nutrició humana, com per exemple, la digestió (Teixeira, 2000), la respiració (Huey-Lien, 2007), la circulació (Arnaudin \& Mintzes, 1985), la excreció (Yip, 1998) i la representació de la cèl-lula i els seus processos (Flores, Tovar \& Gallegos, 2003); han permès identificar algunes de les concepcions alternatives de l'alumnat més habituals $i$, en alguns casos, associar-les als errors en la integració dels processos.

No obstant això, degut a que la integració dels processos que formen part de la nutrició humana és essencial per tal d'assolir una visió integradora i no compartimentada del cos humà, calen estudis que aprofundeixin sobre les concepcions alternatives en relació a les connexions entre els processos i, no tant, en els processos aïllats.

Dos recerques que aprofundeixen en la integració dels processos són: Núñez, F.; Banet, E. (1997). "Students' conceptual patterns of human nutrition"; i Banet, E.; Núñez, F. (1997). "Teaching and learning about human nutrition: a constructivist approach", International Journal of Science Education. Aquestes ens han permès fonamentar l'aproximació teòrica i metodològica d'aquest treball que es presenta.

\section{OBJECTIUS, PREGUNTA DE LA RE- CERCA I TASQUES}

La intenció en aquest treball no és el d'indagar únicament sobre les concepcions alternatives de l'alumnat en relació al procés de nutrició humana ni el de reproduir algunes recerques que s'han fet al respecte. Per això, els objectius de la recerca que s'han definit són:

- Analitzar la comprensió de cada connexió entre els diversos processos de la nutrició humana (a través de l'estudi dels ítems d'una rúbrica).

- Identificar les concepcions alternatives que s'hi associen.

- Estudiar fins a quin punt les han superat en finalitzar la Unitat Didàctica.

Per tant, la pregunta de recerca que en resulta és: Quines concepcions presenta l'alumnat en relació al procés de nutrició humana i fins a quin punt les han superat?

\section{METODOLOGIA}

Per tal de donar resposta a la pregunta de recerca, la proposta de tasques a realitzar es desglossa a continuació:

1) Analitzar a fons el contingut per seleccionar quins coneixements cal que l'alumne desenvolupi sobre el procés de nutrició humana.

2) Preparar el material i les activitats a desenvolupar al llarg de la Unitat Didàctica sobre nutrició humana per a tal finalitat.

3) Construir una rúbrica que agrupa 11 connexions (o codis) entre els diferents processos a integrar sobre la nutrició humana per tal de recollir les dades de l'alumnat sobre les connexions entre els processos de la nutrició humana.

4) Desenvolupar les activitats programades i fer les modificacions oportunes al llarg del procés d'execució de la Unitat Didàctica.

5) Observar les respostes en relació al què han contestat sobre el procés de nutrició humana durant l'execució de la Unitat Didàctica.

6) Observar les respostes en relació al què han contestat sobre el procés de nutrició humana en finalitzar la Unitat Didàctica, a través d'una de les preguntes de la prova final escrita.

7) Comparar les respostes durant i després de la Unitat Didàctica i comprovar si els resultats esperats coincideixen amb els què hem obtingut.

8) Descriure propostes de millora de la Unitat Didàctica a partir dels resultats i les conclusions de la recerca. 
Les dades o evidències que s'han recollit i que a través del seu anàlisi mitjançant la rúbrica i posterior discussió ens han permès fonamentar les conclusions de la recerca han estat:

- Els resultats de les preguntes a) i b) de l'enquesta sobre l'autopercepció abans i després de la Unitat Didàctica (Figura 1).

1. Contesta a les següents preguntes segons el teu grau de coneixement (SI/R/NO), Sabries

\begin{tabular}{|c|c|c|c|c|c|c|}
\hline dir... & & & & & & \\
\hline Sabries dir... & SI & $R$ & NO & SI & $\mathrm{R}$ & NO \\
\hline $\begin{array}{l}\text { a) La diferencia entre un aliment i un } \\
\text { nutrient? }\end{array}$ & & & & & & \\
\hline $\begin{array}{l}\text { b) Com i per què les cèllules del nostre cos } \\
\text { es nodreixen? }\end{array}$ & & & & & & \\
\hline $\begin{array}{l}\text { c) Les diferències entre una proteina I un } \\
\text { glúcid? I entre un glúcid i un lipid? }\end{array}$ & & & & & & \\
\hline $\begin{array}{l}\text { d) Les diferències entre un aliment } \\
\text { energètic, formador i regulador? }\end{array}$ & & & & & & \\
\hline $\begin{array}{l}\text { e) La quantitat d'energia neçessària per } \\
\text { viure? }\end{array}$ & & & & & & \\
\hline $\begin{array}{l}\text { f) Algun trastorn alimentari i les seves } \\
\text { conseqüencies? }\end{array}$ & & & & & & \\
\hline
\end{tabular}

Figura 1. Enquesta sobre autopercepció sobre els continguts de nutrició humana.

- Les produccions de l'alumnat durant la Unitat Didàctica sobre diverses qüestions (preguntes 1 i 4 de l'activitat 1 i preguntes 2 i 3 de l'activitat 2) i les produccions després de la Unitat Didàctica (pregunta 2 de l'avaluació final. Figura 2).

2. Els ciclistes professionals que participen en el Tour de França, el Giro d'Ità lia i la Volta a Espanya prenen gels durant les etapes per evitar baixades d'energia importants degut a l'esforçi poder disputar aquestes etapes sense por a que el seu rendiment baixi de sobte. Aquests gels aporten energia de forma immediata a les cèl-lules musculars dels ciclistes:

a) Segons aquesta informació, quin diries que és el nutrient principal dels gels? Justifica la teva resposta. [1 punt]

b) Aplica el que has après al llarg d'aquestes sessions per explicar, tan detalladament com puguis, com els nutrients que contenen els gels que prenen els cidistes els hi arriben a les cèl-lules musculars $i$ com aquestes n'obtenen l'energia que necessiten.

La teva explicació cal que contingui, com a mínim, les següents paraules: aliment, nu trient, oxigen, cèllul a, energia, mitocondri i respiració cel·lu lar. [2 punts]

Figura 2. Pregunta 2 de l'avaluació final de la UD.

Per últim, mencionar que aquesta recerca s'ha dut a terme amb els i les alumnes d'un grup de $3 r$ d'ESO de l'Institut Lluís de Peguera (Manresa) on he implementat la Unitat Didàctica sobre nutrició humana en el marc del "Practicum" del Màster de Formació de Professorat de Secundària de la Universitat Autònoma de Barcelona (UAB).

\section{RESULTATS}

\section{Anàlisi i discussió de l'enquesta d'au- topercepció}

Els resultats de l'enquesta del nivell d'autopercepció en relació als seus coneixements envers les qüestions sobre nutrició humana, abans i després de la Unitat Didàctica, es mostren a continuació:

Abans de la realització de la Unitat Didàctica sobre Nutrició Humana:

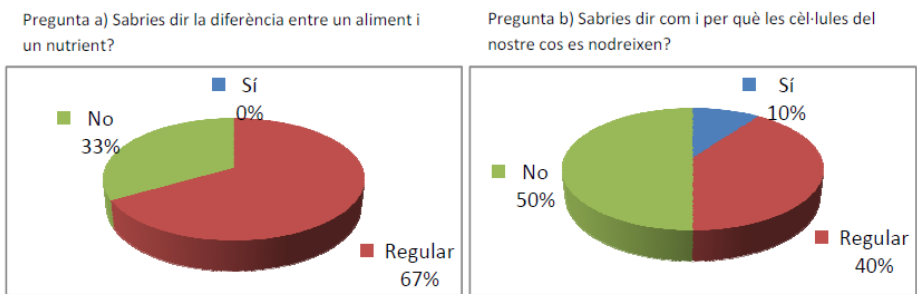

Després de la realització de la Unitat Didàctica sobre Nutrició Humana:

Pregunta a) Sabries dir la diferència entre un aliment $i \quad$ Pregunta b) Sabries dir com i per què les cèl-lules del un nutrient? nostre cos es nodreixen?

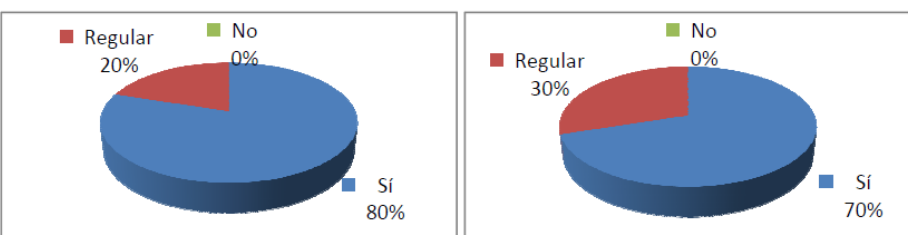

Figura 3. Gràfics circulars on es representa el percentatge d'alumnes segons el seu grau d'autopercepció abans i després de la UD en relació a les preguntes: a) Sabries dir al diferència entre un aliment i un nutrient i; b) Sabries dir com i per què les cèl-lules del nostre cos es nodreixen?

Com s'observa pel que fa a la pregunta "Sabries dir la diferència entre un aliment i un nutrient?", inicialment un $33 \%$ considerava que no sabia la diferència entre aliment i nutrient, mentre que un $67 \%$ considerava que no ho tenia del tot clar. En canvi, al finalitzar la Unitat Didàctica un $80 \%$ creia ser capaç de dir la diferència entre aliment i nutrient, mentre que l'alumnat que encara no ho tenia clar del tot va disminuir del $33 \%$ al $20 \%$. Per la seva banda, els resultats inicials a la pregunta "Sabries dir com i per què les cèl-lules del nostre cos es nodreixen?" mostraven que un $50 \%$ deia que no ho sabria explicar, un $40 \%$ deia que ho sabria explicar a mitges i un $10 \%$ deia que ho sabria explicar. En canvi, al final de la Unitat Didàctica el percentatge d'alumnes que creu que ho sabria explicar a mitges es reduiria al $30 \%$ mentre que els que ho sabrien explicar correctament augmentaria al $70 \%$.

Aquests resultats obtinguts són excel-lents des d'un punt de vista docent: l'alumnat que creia tenir un coneixement "baix" o nul i un coneixement "mitjà" 
ha descendit en tots dos casos (assolint el $0 \%$ quant a una percepció de coneixement "baix" o nul en tots dos casos), mentre que l'alumnat que creia tenir un coneixement "avançat" ha augmentat significativament. El fet que s'identifiqui un menor percentatge que creia assolir un coneixement "avançat" pel cas de la segona pregunta respecte a la primera s'explica ja que l'alumnat partia des d'una posició més desafavorida abans d'impartir la Unitat Didàctica.

Malgrat la importància d'aquests resultats, cal tenir present que aquests resultats tan sols mostren l'evolució de l'autopercepció. Podria ser que l'alumnat percebés que ha millorat el seu coneixement envers al procés de nutrició humana però, en canvi, aquesta percepció fos errònia i no es correspongués a una evolució real. En aquest sentit, cal analitzar les produccions de l'alumnat ha elaborat durant $\mathrm{i}$ després de la Unitat Didàctica per tal d'observar si aquesta evolució és real o no.

\section{Anàlisi i discussió de les produccions de l'alumnat}

Les produccions de l'alumnat recollides durant $\mathrm{i}$ després de la realització de la Unitat Didàctica presenten una gran diversitat $i$ aquest fet ha dificultat poder establir patrons específics i comuns que facilitin la classificació de les respostes de l'alumnat.

Per aquest motiu, l'anàlisi d'aquestes produccions es basarà, primerament, en estudiar una per una cadascuna de les connexions entre els diversos processos que formen part de la nutrició humana per tal de veure quin és el nombre d'alumnat que els ha relacionat correctament durant i després de la Unitat Didàctica i quines són les concepcions de l'alumnat que hi ha al darrera. En segon lloc, es passarà a l'estudi de l'evolució de tres grans models sobre la nutrició humana (model no integrat/no relacionat, model no integrat/relacionat i model integrat/relacionat) a nivell individual.

\section{Anàlisi dels resultats abans i després de la Unitat Didàctica}

Els resultats de l'anàlisi de les produccions de l'alumnat durant i després de la realització de la Unitat Didàctica, que s'han obtingut gràcies a la codificació de les respostes escrites mitjançant una rúbrica, es mostren a continuació de forma esquemàtica. Com es pot visualitzar en la figura 4 (durant la realització de la Unitat Didàctica) hi ha cinc relacions que inicialment resulten problemàtiques per a l'alumnat: el pas d'oxigen del sistema respiratori al sistema circulatori; el pas de l'oxigen del sistema circulatori a totes les cèl-lules del cos; la producció de residus degut al procés de respiració cel-lular; el pas de residus de les cèl-lules al sistema circulatori; i el pas de residus del sistema circulatori al sistema respiratori i/o excretor per a ser eliminats. Per la seva banda, tan sols dos relacions són introduïdes per una bona part de l'alumnat: el pas dels nutrients al sistema circulatori, i l'obtenció d'oxigen per part dels pulmons i el sistema respiratori.

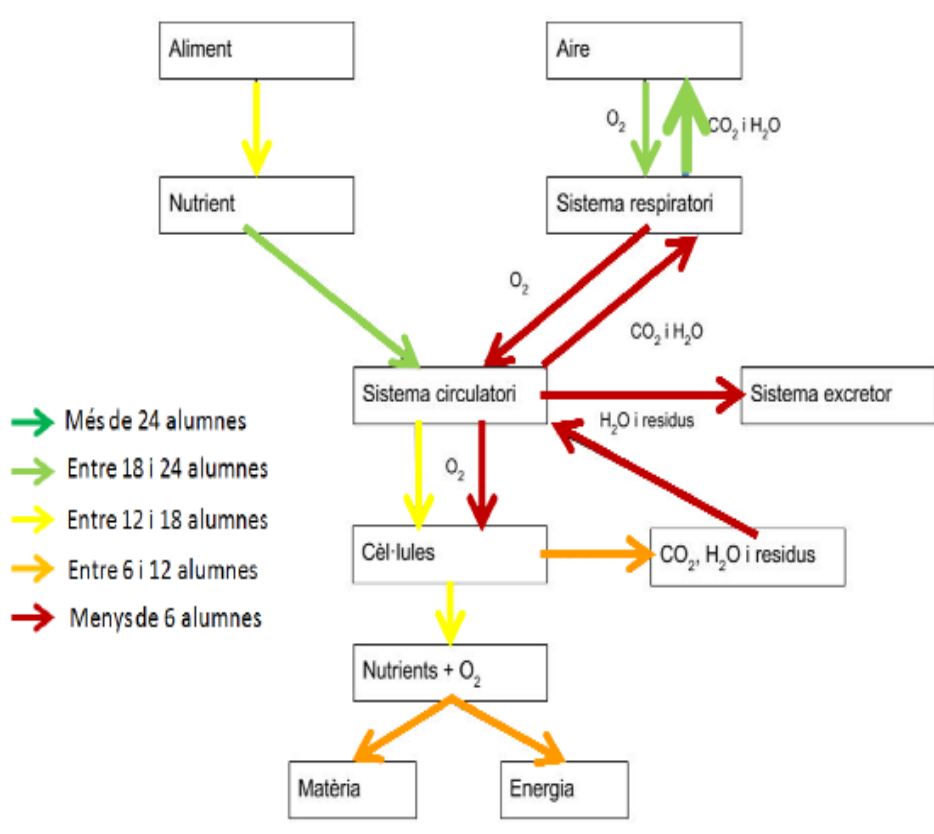

Figura 4. Mapa conceptual en què es representa el procés de nutrició humana, les relacions entre els processos que seran objecte d'estudi i el nombre d'alumnat que descriuen aquestes relacions durant la realització de la Unitat Didàctica, a través del codi de colors de la llegenda.

En el mapa conceptual de la figura 5 s'identifiquen augments molt significatius en relació al de dalt com els observats en el pas d'aliment a nutrient i el pas d'obtenció de matèria i energia a partir dels nutrients en les cèl-lules del nostre organisme. Tot $i$ això, també es produeixen augments molt petits com el pas de residus al sistema circulatori $i$, fins i tot nuls, com el pas de l'oxigen del sistema respiratori al sistema circulatori.

Però, en termes generals, si ens fixem en l'evolució global del grup classe quan comparem els mapes conceptuals entre si, s'observa que el nombre d'alumnes que estableixen les diferents relacions ha augmentat significativament, com s'evidencia per 
l'augment de fletxes de color verd (major nombre d'alumnat) en relació amb les de color vermell (menor nombre d'alumnat). Si es representa aquesta comparació entre el durant i el després a través d'un histograma presentat en la figura 6.

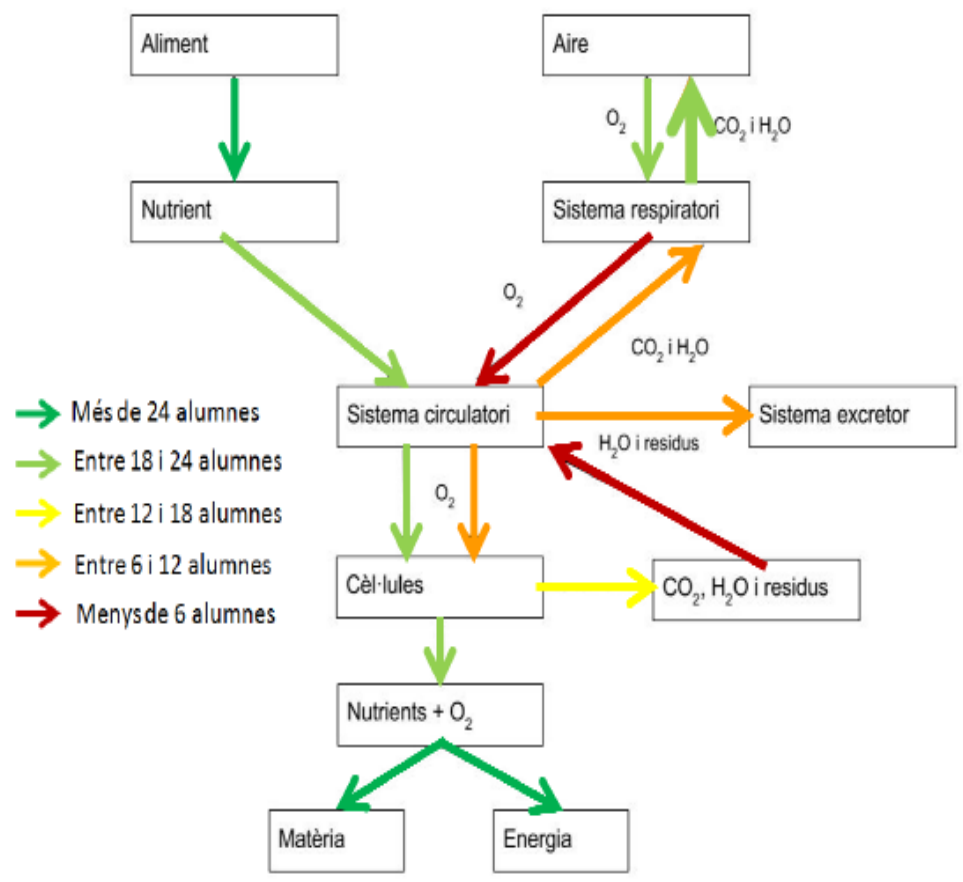

Figura 5. Mapa conceptual en què es representa el procés de nutrició humana, les relacions entre els processos que seran objecte d'estudi i el nombre d'alumnat que descriuen aquestes després de la realització de la Unitat Didàctica, a través del codi de colors de la llegenda.
Entre els augments més significatius es troba com dèiem l'alumnat que explica el pas d'aliment a nutrient - que passa del $50 \%$ al $93 \%$-; el pas dels nutrient del sistema circulatori a totes les cèl-lules de l'organisme - que passa del $43 \%$ al $70 \%$-; i, també, el procés d'obtenció de matèria i energia a partir dels nutrients en les cèl-lules del nostre organisme - que passa del $40 \%$ al $80 \%$-; i la producció de residus degut al procés de respiració cel-lular - que passa del $27 \%$ al $50 \%-$. Mentre que no s'acaba de concretar com arriba l'oxigen dels pulmons al sistema circulatori - que es queda en el $13 \%$ - ni com aquest oxigen passa de la sang a totes les cèl·lules de l'organisme - que passa del $17 \%$ al $20 \%$ - , tot i que sí que s'especifica que l'oxigen intervé activament en el procés d'obtenció de matèria i energia. Tampoc, com s'acaben eliminant els residus generats en la respiració cel-lular, és a dir, el pas de les cèl-lules al sistema respiratori - que passa del $7 \%$ al $10 \%$ - i del sistema circulatori al sistema respiratori i/o excretor - que passa d'un $13 \%$ al $23 \%$-.

Aquesta representació confirma l'augment significatiu del percentatge d'alumnat que identifica les diferents relacions entre els processos i, per tant, un augment del nivell de comprensió de la nutrició humana en el grup d'estudi. Més d'un $60 \%$ de l'alumnat ha identificat 6 de les 11 relacions entre processos al final de la Unitat Didàctica, quan a l'inici només eren 2.

Tot i així, segueixen existint relacions entre processos que no s'expliquen amb detall per part d'aproximadament un $80 \%$ de l'alumnat i que coincideixen amb les què majoritàriament no eren considerades per l'alumnat a l'inici.

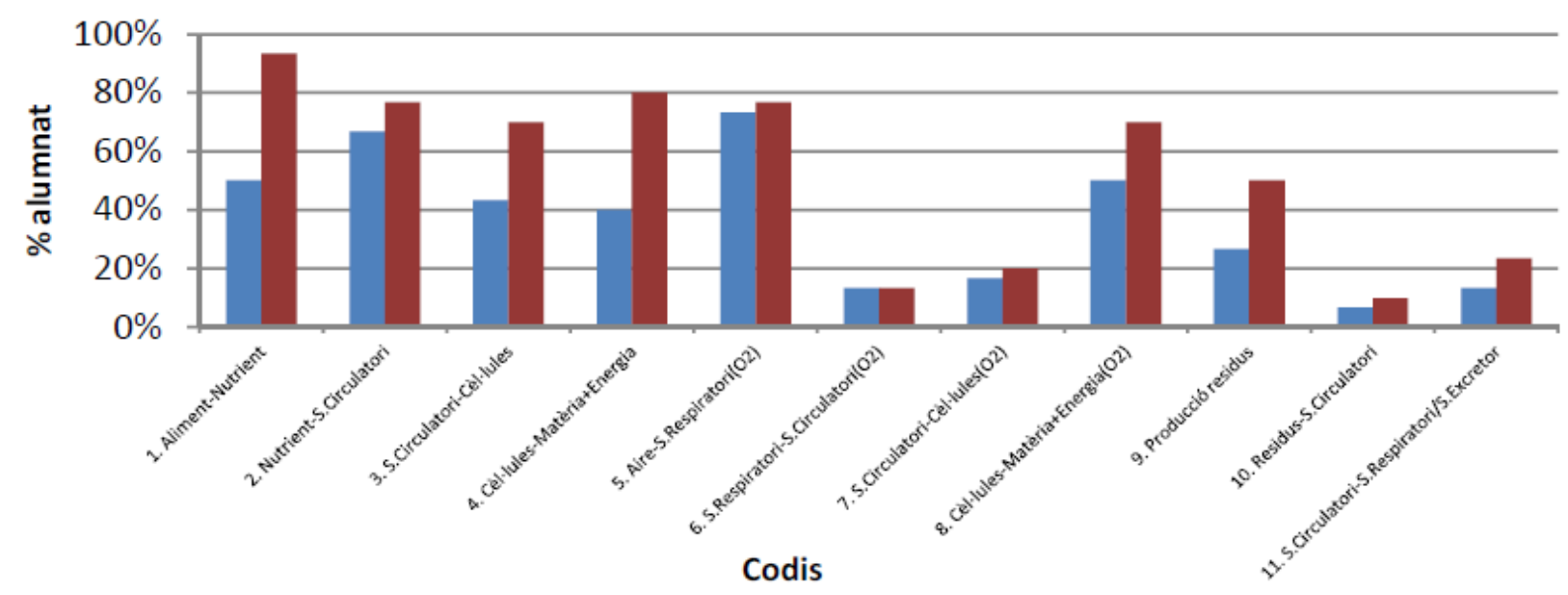

Figura 6. Histograma en què es compara el percentatge d'alumnat que descriu correctament cadascuna de les relacions entre processos durant l'execució de la Unitat Didàctica (en blau) i després de la Unitat Didàctica (en vermell). 


\section{Anàlisi de l'evolució individual de les produccions de l'alumnat a través dels models}

Per entendre a nivell individual quin ha estat l'efecte de les activitats proposades quant a la modificació de les concepcions de l'alumnat sobre la nutrició humana, s'ha portat a terme una anàlisi del desenvolupament conceptual a partir dels models proposats per Núñez i Banet (1997) entre el durant i el després de la Unitat Didàctica. Aquests tres models són:

- Model no integrat / no relacionat:

Aquell en el que s'inclouen aquelles concepcions que mostren una visió compartimentada dels processos que engloben la nutrició humana. En concret, en aquest model s'identifica la digestió i la respiració com processos aïllats i que no es relacionen directament amb la nutrició.

- Model no integrat / relacionat:

Aquell en el que s'agrupen les concepcions en les quals s'identifiquen algunes connexions entre els processos de la nutrició humana, tot i que s'observa que no s'entén la nutrició humana com un procés que integra altres processos. En aquest model, per exemple, s'assenyala que el destí dels nutrients i de l'oxigen són les cèl/lules però no saben com i tampoc expliquen correctament la producció de residus i el seu procés d'eliminació.

- Model integrat / relacionat:

Aquell en el que s'inclouen les concepcions que expliquen correctament la nutrició humana, és a dir, en el que s'estableixen les connexions entre els processos i s'adquireix una visió global i integrada.

Els resultats de l'anàlisi de l'evolució en les produccions, segons aquests tres models, és el següent:

\begin{tabular}{|l|l|l|}
\hline $\begin{array}{l}\text { Model inicial } \\
\text { (durant la UD) }\end{array}$ & $\begin{array}{l}\text { Model final } \\
\text { (després la UD) }\end{array}$ & Nombre d'alumnes \\
\hline Model 1 & Model 1 & 7 \\
\hline Model 1 & Model 2 & 10 \\
\hline Model 1 & Model 3 & 2 \\
\hline Model 2 & Model 1 & 0 \\
\hline Model 2 & Model 2 & 3 \\
\hline Model 2 & Model 3 & 3 \\
\hline Model 3 & Model 1 & 0 \\
\hline Model 3 & Model 2 & 0 \\
\hline Model 3 & Model 3 & 3 \\
\hline No respon & & 2 \\
\hline
\end{tabular}

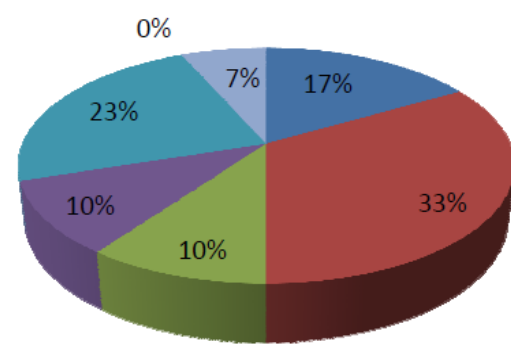

- Reconstrucció total

Reconstrucció parcial

Manté model integrat/relacionat

- Manté model no integrat/relacionat Manté model no integrat/no relacionat

Figura 7. Gràfic circular que representa l'evolució conceptual de l'alumnat en relació al model inicial i final sobre la nutrició humana segons els models descrits per Núñez i Banet (1997).

Per un costat, aquests resultats destaquen l'absència de regressió en la comprensió de la nutrició humana, és a dir, que no hi ha cap alumne que passi d'un model a un altre que s'allunyi del model integrat / relacionat que es vol aconseguir. En concret, aquesta dada és important en tant que l'alumnat que se situava dintre d'un model integrat / relacionat segueix mantenint-lo (10\%).

Per altre costat, també destaca la reconstrucció produïda després de la Unitat Didàctica a través de la incorporació de nous coneixements que han ajudat a reorganitzar les seves idees i a modificar les concepcions inicials d'un $50 \%$ de l'alumnat. En alguns casos, la reconstrucció ha estat total (17\%), el que significa que s'han integrat correctament els diferents processos de la nutrició humana (model integrat / relacionat). En altres casos, l'alumnat ha reconstruït parcialment el seu coneixement (33\%), passant d'un model no integrat / no relacionat a un model no integrat / relacionat, molt més proper al coneixement científic. No obstant això, aquests resultats també assenyalen que un elevat percentatge d'alumnat $(23 \%)$ se segueix mantenint en el model incorrecte (el model no integrat / no relacionat).

\section{Discussió dels resultats}

Darrera d'aquests resultats referits a les relacions que no han estat explicades correctament per l'alumnat, s'amaguen diverses concepcions alternatives que l'alumne presenta abans de l'ensenyament formal. En concret, les concepcions de l'alumnat que s'han pogut associar a l'absència de les relacions entre processos identificades durant la realització de la Unitat Didàctica són les següents:

- El procés de digestió és considerat un procés tancat en si mateix: l'aliment passa per l'aparell 
digestiu fins que és expulsat. En alguns casos, es relaciona l'aliment amb el procés de respiració cel.lular, però de forma errònia, sense considerar que de l'aliment s'obtenen nutrients. En concret, es diu: "l'aliment es barreja amb oxigen i s'obté matèria i energia".

- El procés de captació i utilització de l'oxigen és un procés exclusivament del sistema respiratori, on l'oxigen és captat pels pulmons i és expulsat en forma de diòxid de carboni. En alguns casos, se sap que l'oxigen intervé en la respiració cel·lular, ja que es va mencionar a classe, però no se sap ben bé com intervé en aquest procés perquè s'ignora el paper del sistema circulatori en el transport de l'oxigen.

- El sistema circulatori es considera, en alguns casos, el mitjà de transport dels nutrients a les cèl-lules, però es creu que no totes les cèl.lules necessiten nutrients $i$, per tant, hi ha algunes que fan la respiració cel.lular i altres que no.

- El procés d'obtenció de matèria i energia es produeix en l'intestí i que l'energia i la matèria són les que es transporten a través del sistema circulatori a totes les cèl-lules de l'organisme.

- L'eliminació de residus es concep com un sistema de neteja del nostre organisme però que no està lligat amb la respiració cel.lular. $\mathrm{El} \mathrm{CO}_{2}$, el $\mathrm{H}_{2} \mathrm{O}$ i els residus no tenen res a veure amb el procés d'obtenció de matèria i energia i són substàncies que tenim en el nostre cos $i$ que s'han d'eliminar. En el cas que es consideri que estigui relacionat amb la respiració cel-lular, es creu que aquests residus es produeixen tan sols en el sistema respiratori i/o en el sistema excretor on s'eliminen, però no hi ha un procés de transport de les cèl-lules a la sang i de la sang al sistema respiratori i/o excretor.

Els resultats obtinguts després de l'execució de la Unitat Didàctica, mostren una clara millora de les produccions de l'alumnat que està relacionada amb la modificació de la majoria de les concepcions que l'alumnat presentava durant l'execució de la Unitat Didàctica:

- El procés de digestió ja no es considera un procés tancar per si mateix, sinó que es tracta d'un procés pel qual s'obtenen els nutrients dels aliments, que seran aprofitats pel nostre organisme en el procés de nutrició que engloba altres processos i sistemes d'òrgans.

- El procés de captació i utilització d'oxigen ja no és un procés exclusivament del sistema respiratori, entre altres perquè se sap que l'oxigen arriba a totes les cèl-lules i que el diòxid de carboni es produeix en les cèl-lules degut a la respiració
cel-Iular. Tot i així, encara no se sap com l'oxigen intervé en la respiració cel-lular.

- El sistema circulatori transporta els nutrients a totes les cèl-lules del cos i no només a unes quantes com es creia prèviament, perquè totes les cèl-lules necessiten nutrients per obtenir matèria i energia, ja que és imprescindible per viure.

- La respiració cel-lular es dóna a les cèl-lules del nostre organisme i, per tant, són els nutrients (i no l'energia i la matèria) els que es transporten a través de la sang fins a les cèl-lules i és en elles on s'obté l'energia i la matèria.

- La producció de residus que cal eliminar ja no es deslliga del procés de respiració cel-lular, sinó que es tracta d'un producte d'aquest procés, tot i que no s'acaba d'explicar com s'acaben eliminant de l'organisme.

\section{CONCLUSIONS}

A través d'aquest estudi es pretenia donar resposta a la pregunta "Quines concepcions presenta l'alumnat en relació al procés de nutrició humana i fins a quin punt les han superat?" a través de 3 objectius principals: analitzar la comprensió de cada connexió entre els diversos processos de la nutrició humana; identificar les concepcions alternatives que s'hi associen; i estudiar fins a quin punt les han superat en finalitzar la Unitat Didàctica.

Respecte al primer dels objectius, s'han pogut identificar connexions errònies entre les que destaquen, segons l'alumne, el pas d'aliment a nutrients i la seva distribució a totes les cèl-lules per obtenir matèria i energia, el pas de l'oxigen del sistema respiratori a les cèl-lules a través del sistema circulatori i la producció i l'eliminació dels residus a través de la sang i els sistemes respiratori i excretor.

Respecte al segon, s'ha detectat que aquestes connexions errònies van associades a concepcions alternatives de l'alumnat, prèvies a l'ensenyament formal, sobre certs aspectes clau de la nutrició humana que malgrat ser incorrectes tenen una certa lògica des de la seva perspectiva i representen les seves teories sobre aquest procés. Unes concepcions que coincideixen amb altres reportades en estudis anteriors (Teixeira, 200; Huey-Lien, 2007; Arnaudin \& Mintzes, 1985; Yip, 1998; Flores, Tovar \& Gallegos, 2003), allunyades del coneixement científic acceptat i que es corresponen amb models de coneixement no integrats. És a dir, que malgrat pot ser que relacionin diversos processos entre si, no mostren una visió global que integri els diferents processos que es desenvolupen en la nutrició humana. 
Quant a la progressió de l'alumnat, els resultats obtinguts mostren que la proposta didàctica ha ajudat a una gran part de l'alumnat (el 50\% del grup classe) a modificar les seves concepcions i a construir models sobre la nutrició humana que relacioni $\mathrm{i}$ integri els diversos fenòmens. Tot i així, hi ha un elevat percentatge de l'alumnat (un $23 \%$ ) que, malgrat ha progressat quant al seu coneixement sobre la nutrició humana, segueix mantenint models erronis (model no integrat / no relacionat) fonamentats en les seves concepcions alternatives prèvies a l'ensenyament formal. Aquesta situació fa visible l'elevada persistència i estabilitat de les concepcions alternatives de l'alumnat.

Per últim, cal remarcar que el fet que l'estudi només compti amb la mostra de 30 alumnes, fa que aquesta mostra de població utilitzada i que l'estudi es limiti a un context local i a un grup classe, aquesta no sigui tan representativa com es voldria però marca un punt de partida per a posteriors recerques.

\section{AGRAIIMENTS}

Les autors agraeixen a l'Institut Lluís de Peguera de Manresa i, en especial a la tutora del centre, Montserrat Amich, la càlida acollida, el suport en tot moment i la col-laboració en la recerca.

\section{BIBLIOGRAFIA}

ARNAUDIN, M.W.; MINTZES, J.J. (1985). Students alternative conceptions of the Human Circulatory System: a cross-age, Science Education, 69:5, 721-733.
BANET, E.; NÚÑEZ, F. (1997). Teaching and learning about human nutrition: a constructivist approach, International Journal of Science Education, 19:10, 1169-1194.

DRIVER, R.; GUESNE, E.; TIBERGHEIN, A. (1994). Children's Ideas and the learning of science en Children's Ideas in Science.

FLORES, F.; TOVAR, M.A.; GALLEGOS, L. (2003). Representation of the cell and its processes in high school students: An integrated view, International Journal of Science Education, 25:2, 269286.

HUEY-LIEN, K. (2007). A Study of Aboriginal and Urban Junior High School Students' Alternative Conceptions on the Definition of Respiration, International Journal of ScienceEducation, 29:4, 517-533.

NÚÑEZ, F.; BANET, E. (1997). Students' conceptual patterns of human nutrition, International Journal of Science Education, 19:5, 509-526.

TEIXEIRA; F.M. (2000). What happens to the food we eat? Children's conceptions of the structure and function of the digestive system, International Journal of Science Education, 22:5, 507-520.

YIP, D.Y. (1998). Alternative conceptions on Excretion and Implications for Teaching, Educational Journal, 26:1, 101-116. 